\title{
PENGARUH INFLASI, JAKARTA ISLAMIC INDEX, BAGI HASIL BANK SYARIAH TERHADAP INVESTASI REKSA DANA SYARIAH
}

\author{
(Studi Empiris pada Reksa Dana Syariah yang Terdaftar di OJK \\ Periode 2013 - 2017) \\ Elan Kurniawan \\ Fakultas Ekonomi dan Bisnis Jurusan Akuntansi \\ Universitas Islam As-Syafi'iyah, Jakarta \\ elan.kurniawan26@gmail.com
}

\begin{abstract}
The purpose of this study is to obtain empirical evidence about the problems discussed, namely "Influence of Inflation, Jakarta Islamic Index, and Profit Sharing of Islamic Banks on Sharia Mutual Investment". Investment is proxied by Net Asset Value of Sharia Funds.

Presentation and analysis of research data in 2013-2017, using descriptive statistical analysis, panel data regression models, data estimation methods namely Chow Test, classical assumption analysis using normality test, multicollinearity test and hypothesis testing.

Based on the results of the analysis of this research data, positive inflation has a significant positive effect on Sharia Mutual Fund Investment, the Jakarta Islamic Index has a significant positive effect on Sharia Mutual Fund Investment, while Sharia Bank Profit Sharing is also significantly negative on Sharia Mutual Fund Investment.
\end{abstract}

Keywords: Inflation, Jakarta Islamic Index (JII), Sharing of Sharia Banks, Sharia Mutual Investment, Coefficient of determination

\begin{abstract}
Abstrak
Tujuan dari penelitian ini adalah untuk mendapatkan bukti empiris mengenai masalah yang diteliti tentang Pengruh Inflasi, Jakarta Islamic Index, dan Bagi Hasil Bank Syariah terhadap Investasi Reksa Reksa Dana Syariah Investasi diproksikan dengan Nilai Aktiva Bersih.

Penyajian dan analisis data penelitian pada tahun 2013-2017, menggunakan analisis statistik deskriptif, model regresi data panel, metode estimasi data yaitu Uji Chow, analisis asumsi klasik meliputi uji normalitas, uji multikolinieritas dan uji hipotesis.

Berdasarkan hasil analisis data penelitian ini menunjukkan bahwa Inflasi berpengaruh positif signifikan terhadap Investasi Reksa dana Syariah dana Syariah, Jakarta Islamic Index berpengaruh positif signifikan terhadap Investasi Reksa dana Syariah dana Syariah, sedangkan Bagi Hasil Bank Syariah berpengaruh negatif tidak signifikan terhadap Investasi Reksa dana Syariah.
\end{abstract}

Kata Kunci : Inflasi, Jakarta Islamic Index (JII), Bagi Hasil Bank Syariah, Investasi Reksa dana Syariah, Koefisien determinasi 


\section{Pendahuluan}

Meningkatnya kebutuhan hidup dan banyaknya hal yang tidak dapat terprediksi dalam hidup, membuat masyarakat mulai memikirkan kebutuhan masa depan mereka. Seorang yang bijak akan memikirkan bagaimana berusaha meningkatkan taraf hidupnya. Hal ini yang mendorong orang untuk menyisihkan sebagian dari pendapatannya dalam suatu wadah yang diharapkan akan meningkat nilainya pada masa yang akan datang. Kegiatan ini dinamakan investasi.

Menurut Febrian Dwi Setyarini (2015:1) menyatakan bahwa Investasi merupakan komitmen atas sejumlah dana atau sumber dana lainnya yang dilakukan pada saat ini, yang bertujuan untuk mendapatkan sejumlah keuntungan dimasa yang akan datang. Investasi merupakan suatu kegiatan muamalah yang sangat dianjurkan dalam agama Islam karena dengan berinvestasi, harta akan menjadi produktif dan mendatangkan kebaikan bagi orang lain. Investasi dibagi menjadi dua, yaitu investasi pada financial asset dan investasi pada real asset. Investasi pada financial asset dilakukan pada pasar uang, contohnya sertifikat deposito, commercial paper, Surat Berharga Pasar Uang (SPBU) dan lain-lain. Investasi juga dapat dilakukan di pasar modal, contohnya saham, obligasi dan surat berharga lainnya. Sedangkan investasi pada real asset dapat dilakukan dengan cara membeli asset produktif, pendirian pabrik, pembukaan pertambangan, perkebunan dan lain lain.

Pasar modal merupakan salah satu alternatif investasi bagi masyarakat untuk mendapatkan keuntungan dengan cepat. Pasar modal dipandang sebagai salah satu sarana yang efektif untuk mempercepat akumulasi dana bagi pembiayaan pembangunan melalui mekanisme pengumpulan dana dari masyarakat dan menyalurkan dana tersebut ke sector sector yang produktif. Maka dari itu, penerbitan produk produk investasi di pasar modal sangat penting yaitu sebagai alternatif bagi investor dalam menginvestasikan dananya. Maka dari itu, investor memerlukan sarana yang tepat untuk menyalurkan dananya dengan tujuan mendapatkan keuntungan yang tinggi dari suatu investasi (Fitria Saraswati, 2013:17).

Reksa dana syariah merupakan lembaga intermediari yang membantu surplus unit melakukan penempatan dana untuk selanjutnya diinvestasikan kembali. Selain untuk memberikan kemudahan bagi calon investor berinvestasi di pasar modal, tujuan reksa dana syariah adalah memenuhi kebutuhan investor yang menginginkan keuntungan dari mekanisme investasi yang bersih dan dapat dipertanggungjawabkan secara religius dan tidak bertentangan dengan prinsip-prinsip syariah, misalnya tidak diinvestasikan pada saham-saham atau obligasi dari perusahaan yang pengelolaan atau produknya bertentangan dengan syariat Islam. Seperti pabrik makanan/minuman yang mengandung alkohol, daging babi, rokok, tembakau, jasa keuangan konvensional, serta bisnis hiburan yang berbau maksiat (MUI, 2001).

Febrian Dwi Setyarini, dalam peneli SBIS, Inflasi, Nilai tukar rupiah, Jumlah uang beredar dan IHSG terhadap Nilai aktiva bersih Reksa dana syariah positif dan signifikan terhadap Nilai Aktiva Bersih (NAB) reksa dana syariah.

Kasyfurrohman Ali, dalam penelitian mikroekonomi terhadap reksadana syariah 
bahwa inflasi berpengaruh positif signifikan terhadap NAB reksa dana syariah. Sementara variabel JII tidak memiliki pengaruh yang signifikan terhadap NAB reksa dana syariah di Indonesia.

Apriliana Ika, dalam penelitiannya menemukan Inflasi dan indeks JII mempunyai pengaruh positif terhadap NAB. Sedangkan return dan risiko tidak berpengaruh terhadap NAB reksa dana syariah.

Dari uraian latar belakang diatas, maka peneliti memutuskan untuk melakukan penelitian dengan mengambil judul Yaitu "Pengaruh Inflasi, Jakarta Islamic Indeks (JII) Dan Bagi Hasil Bank Syariah Terhadap Investasi Reksa Dana Syariah Periode $2013-2017 \%$.

\section{Perumusan Masalah}

Berdasarkan uraian dari latar belakang yang telah ada, maka perumusan masalahnya sebagai berikut:

1. Bagaimana pengaruh Inflasi terhadap Investasi Reksa dana Syariah ?

2. Bagaimana pengaruh Jakarta Islamic Indeks (JII) terhadap Investasi Reksa dana syariah?

3. Bagaimana pengaruh Bagi Hasil Bank Syariah terhadap Investasi Reksa dana Syariah?

\section{Tujuan Penelitian}

Berdasarkan latar belakang dan penelitian terdahulu di atas, adapun tujuan dari penelitian ini adalah:

1. Untuk mengetahui pengaruh Inflasi terhadap Investasi Reksa dana syariah.

2. Untuk mengetahui pengaruh Jakarta Islamic Indeks (JII) terhadap Investasi Reksa dana syariah.

3. Untuk mengetahui pengaruh Bagi Hasil Bank Syariah terhadap Investasi Reksa dana syariah.

\section{Tinjauan Pustaka}

Signaling Theory

Brigham (2011) menyatakan Signaling theory adalah suatu tindakan yang diambil manajemen suatu perusahaan yang memberi informasi dan petunjuk bagi investor tentang bagaimana manajemen memandang prospek perusahaan. Reaksi pasar ditunjukkan dengan adanya perubahan harga saham pada waktu informasi diumumkan dan pelaku pasar menerima informasi tersebut, dimana pelaku pasar terlebih dahulu menganalisis informasi tersebut sebagai sinyal baik (good news) atau sinyal buruk (bad news).

\section{Inflasi}

Inflasi merupakan proses kenaikan harga-harga umum secara terus menerus. Berdasarlan sifatnya Inflasi dibedakan menjadi beberapa golongan yaitu inflasi ringan, 
inflasi sedang, inflasi berat dan hiperinflasi (Agustina, 2014).

\section{Jakarta Islamic Index (JII)}

Dalam rangka pengembangan pasar modal syariah, PT Bursa Efek Jakkarta (BEJ) terhitung tanggal 3 Juli 2000 telah meluncurkan indeks saham yang dibuat berdasarkan syariah Islam, yaitu Jakarta Islamic Index (JII). JII terdiri atas 30 jenis saham yang dipilih dari saham-saham yang sesuai dengan syariah Islam (Mursyidin, 2010).

\section{Bagi Hasil Bank Syariah}

Nisbah adalah rasio atau perbandingan pembagian keuntungan (bagi hasil) antara shahibul maal (pemilik dana) dan mudhorib (pengelola). Bagi hasil adalah bentuk return dari kontrak investasi, dan waktu ke waktu, tidak pasti dan tidak tetap. Besar kecilnya return tergantung pada hasil usaha (Syailendra, 2017).

\section{Nilai Aktiva Bersih (NAB) Reksa Dana Syariah}

NAB reksa dana syariah adalah nilai yang menggambarkan total kekayaan bersih reksa dana syariah setiap harinya.

\section{Hipotesis}

H1 : Inflasi berpengaruh Negatif terhadap Investasi Reksa Dana Syariah di Indonesia H2 : JII berpengaruh Positif terhadap Investasi Reksa Dana Syariah di Indonesia.

H3 : Bagi hasil berpengaruh Negatif terhadap Investasi Reksa Dana Syariah di Indonesia.

\section{Kerangka Pemikiran}

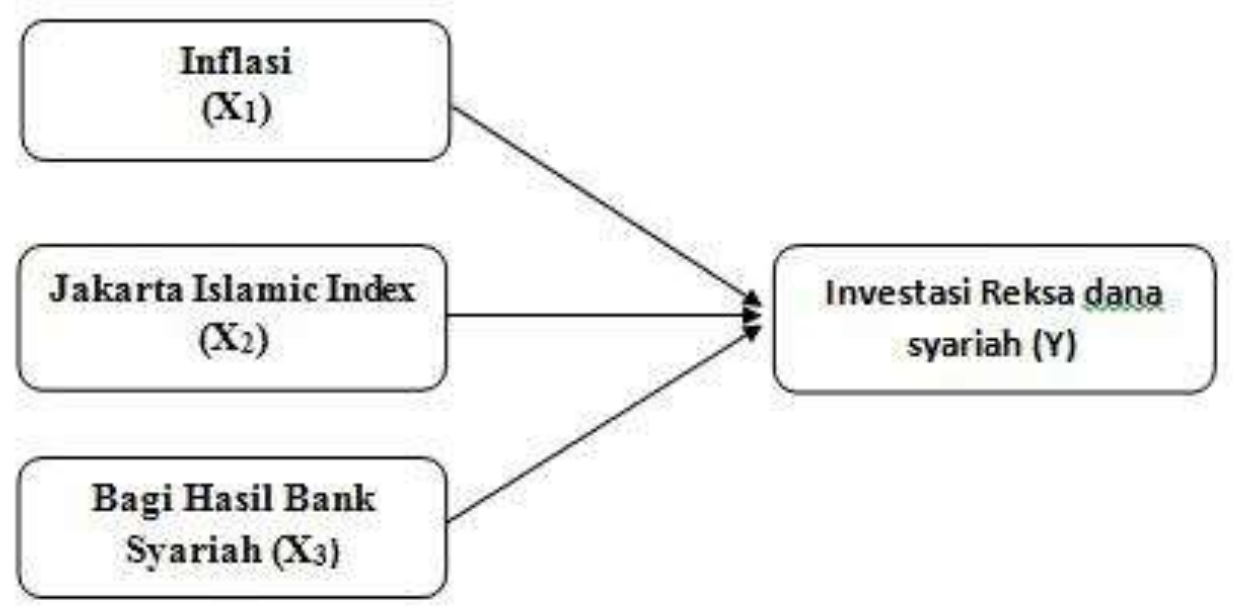

Keterangan :

$\mathrm{H}_{1}$ : Inflasi berpengaruh Negatif terhadap Investasi Reksa Dana Syariah di Indonesia $\mathrm{H}_{2}$ : Jakarta Islamix Index berpengaruh Positif terhadap Investasi Reksa Dana

Syariah di Indonesia 
$\mathrm{H}_{3}$ : Bagi hasil bank syariah berpengaruh Negatif terhadap Investasi Reksa Dana Syariah di Indonesia.

\section{Metodologi Penelitian}

\section{Populasi, Sampel dan Sampling}

Populasi dalam penelitian ini adalah seluruh reksa dana syariah yang dikeluarkan oleh perusahaan manajer investasi yang terdaftar BAPEPAM-LK pada periode 20132017. Sampel dalam penelitian ini menggunakan metode purposive sampling, yaitu memilih sampel berdasarkan kriteria tertentu. Sampel dalam penelitian ini adalah reksa dana syariah yang terdaftar di BAPEPAM-LK dan berturut turut terdaftar dalam periode $2013-2017$.

Penelitian ini menggunakan metode kuantitatif atau menggunakan data yang dapat diukur dalam skala numerik/angka, yaitu penelitian berdasarkan filsfat positivism, digunakan untuk meneliti pada populasi atau sampel tertentu, pengumpulan data menggunakan instrumen penelitian, analisis data statistik bertujuan untuk menguji hipotesis yang telah ditetapkan dan memperoleh suatu kesimpulan (Herlina Utami, 2017).

\section{Teknik Pengumpulan Data}

Teknik pengumpulan data yang digunakan adalah teknik dokumentasi yaitu dengan mempelajari, mengumpulkan dan menghitung data NAB Reksa dana syariah, Inflasi, JII, dan Bagi Hasil Bank Syariah yang dipublikasi oleh website www.bapepepamlk.go.id, www.ojk.go.id dan www.idx.co.id.

\section{Metode Analisis Data Penelitian}

Beberapa model estimasi data panel, analisis deskriptif dan analisis regresi berganda. Dalam analisis ini dilakukan dengan bantuan program Eviews 9. Dalam penelitian ini menggunakan data panel yang menggabungkan data cross section yang terdir dari 10 perusahaan dan data time series terdiri dari data tahun 2013 sampai dengan 2017.

\section{Hasil Penelitian}

Hasil estimasi model regresi data panel akan menjadi dasar untuk menganalisa dan melakukan pengujian data panel dan dapat disimpulkan bahwa model regresi yang sesuai adalah model regresi fixed effect menggunakan white periode.

Melalui pengloahan data panel menggunakan model estimasi data melalui aplikasi Eviews maka didapatkan output model regresi fixed effect sebagai bahan analisa hipotesis sebagai berikut: 
Hasil Model Fixed Effect

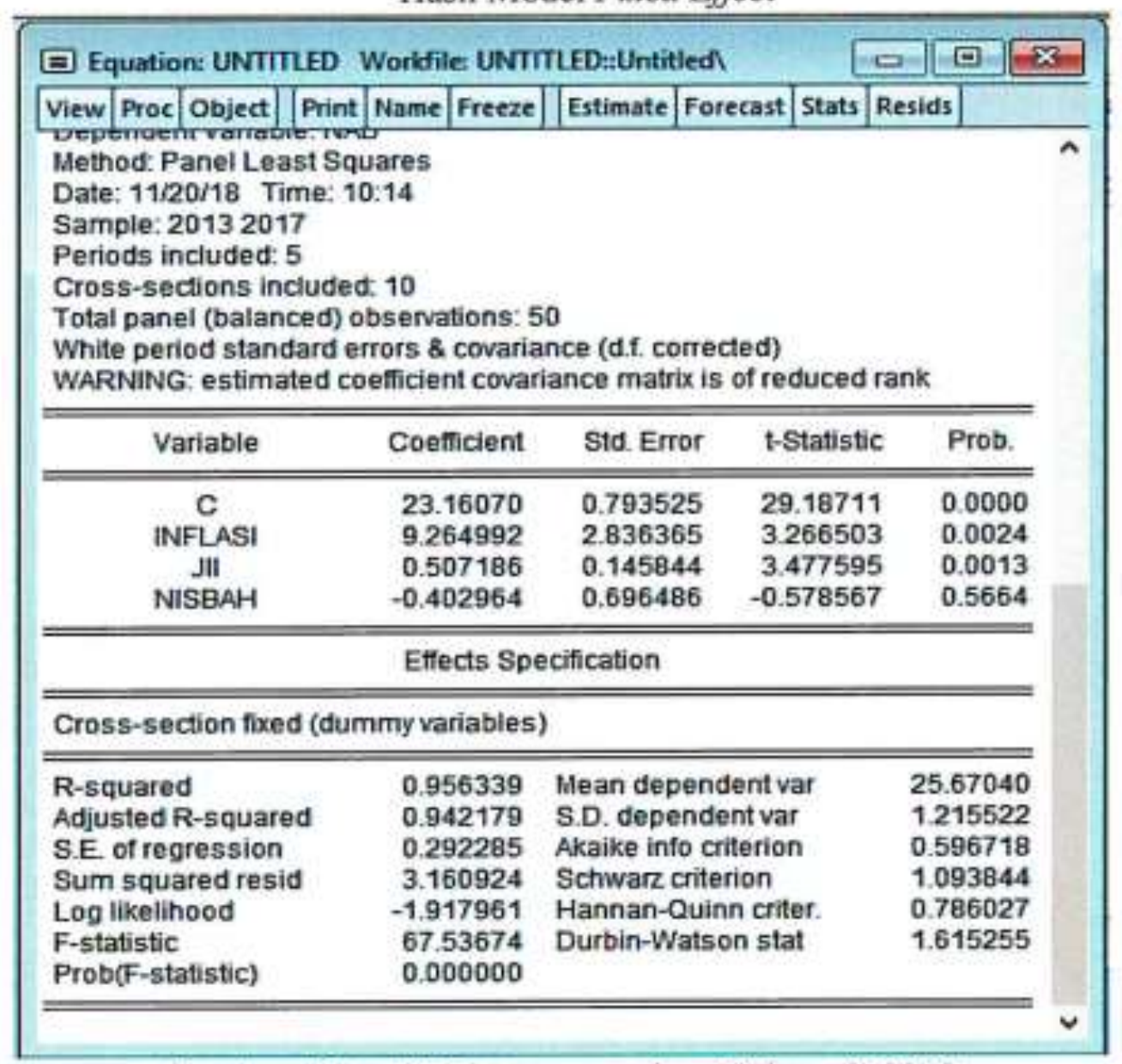

Sumber : Data diolah menggunakan EViews 9, 2018

Dengan hasil model regresi data panel dan persamaan regresi data panel fixed effect diatas, maka akan dijelaskan dan digambarkan atas hasil uji analisis regresi data panel sebagai berikut.

\section{Pengaruh Inflasi terhadap Investasi Reksa dana Syariah}

Hasil penelitian menemukan bahwa Inflasi memberikan pengaruh yang positif dan signifikan terhadap Investasi Reksa dana syariah dengan nilai signifikansi sebesar $0,0024<0,05$. Dengan demikian hasil uji dengan menggunakan uji t diterima dan berpengaruh signifikan terhadap Investasi reksa dana syariah di Indonesia. Jika Inflasi yang terjadi mengalami kenaikan yang stabil maka nilai aktiva bersih meningkat. Hasil ini sesuai dengan penelitian (Setyarini, 2016) yang menyatakan bahwa Inflasi memiliki pengaruh yang positif dan signifikan terhadap Investasi Reksa dana syariah.

\section{Pengaruh JII terhadap Investasi Reksa dana Syariah}

Hasil penelitian menemukan bahwa JII memberikan pengaruh yang positif dan signifikan terhadap Investasi Reksa dana syariah dengan nilai signifikansi sebesar 0,0013 $<0,05$ sebagaimana tertera dalam Hasil Model Fixed Effect. Dengan demikian hasil uji 
dengan menggunakan uji t diterima dan berpengaruh signifikan terhadap Investasi reksa dana syariah di Indonesia. Jika JII meningkat maka nilai aktiva bersih mengalami kenaikan. Hasil ini sesuai dengan penelitian (Apriliana Ika, 2014) yang menyatakan bahwa JII memiliki pengaruh yang positif dan signifikan terhadap Investasi Reksa dana syariah.

\section{Pengaruh Bagi Hasil Bank Syariah Terhadap Investasi Reksa dana Syariah}

Hasil penelitian menemukan bahwa Bagi Hasil Bank Syariah memberikan pengaruh yang negatif dan tidak signifikan terhadap Investasi Reksa dana syariah dengan nilai signifikansi sebesar 0,5664 > 0,05 sebagaimana tertera dalam Hasil Model Fixed Effect. Dengan demikian hasil uji dengan menggunakan uji t diterima, jika bagi hasil kepada nasabah yang besar maka nilai aktiva bersih perusahaan rendah, karena bagian hasil untuk perusahaan kecil sehingga nilai aktiva bersih perusahaan kecil.

\section{Penutup}

\section{Simpulan}

Berdasarkan hasil penelitian yang telah diuraikan pada bab sebelumnya, maka peneliti akan memberikan kesimpulan sebagai berikut:

1. Hasil penelitian menunjukkan bahwa variabel independen yaitu Inflasi berpengaruh signifikan terhadap variabel dependen yaitu Investasi Reksa dana syariah periode 2013 -2017 sehingga $\mathrm{H}_{1}$ ditolak.

2. Hasil penelitian menunjukkan bahwa Jakarta Islamic Index (JII) memberikan pengaruh positif terhadap Investasi Reksa dana syariah periode 2013 -2017 sehingga $\mathrm{H}_{2}$ dapat diterima.

3. Hasil penelitian menunjukkan bahwa variabel independen yaitu Bagi Hasil Bank Syariah berpengaruh negatif terhadap Investasi reksa dana syariah di Indonesia periode 2013 -2017 sehingga $\mathrm{H}_{3}$ dapat diterima.

\section{Saran}

Berikut ini beberapa saran yang akan diberikan peneliti untuk penelitian yang akan dilakukan selanjutnya:

1. Untuk penelitian selanjutnya, disarankan untuk meneliti lebih lanjut tentang Bagi hasil bank syariah berhubung masih terbatasnya rujukan jurnal dan masih perlu banyak yang peneliti belum ketahui.

2. Pengklasifikasian data yang digunakan sebagai sampel pada penelitian ini hanya dengan memenuhi syarat perusahaan yang menerbitkan reksa dana syariah, bisa ditambahkan Perusahaan yang mempunyai website resmi perusahaan dan mempublikasi prospectus perusahaan, karena bagi investor prospectus perusahaan sangat penting untuk menganalisa kinerja beberapa tahun kedepan.

3. Bagi calon investor dan pihak yang terkait dalam kegiatan investasi reksa dana syariah, perlu meningkatkan pemahaman dan kemampuan diri dalam hukum 
ekonomi syariah sehingga dapat memutuskan dengan baik dalam pemilihan investasi yang sesuai.

\section{Referensi}

Aviva, Iza (2016). "Pengaruh Nur Juamlah Uang.Beredar (JUB), Sertifikat Bank Indonesia Syariah (SBIS) dan Jakarta Islamic Index (JII) Terhadap Nilai Aktiva Bersih Reksadana Syarian Periode 2018-2015”, Jakarta: Ind Banking School.

Bank Indonesia (2018). “Bagi Hasil Bank Syariah”, Statistik Perbankan 2013-2017.

DSN MUI No. 20/DSN-MUI/IV/2001 “Pedoman tentang Pelaksanaan Investasi untuk Reksa Dana Syariah”, dalam www.dsnmui.or.id, diakses 28 Oktober 2018.

Esha, Mulya Riyady, Mohamad Heykal. "Analisis Perbandingan Reksa dana Saham Syariah dengan Reksa dana Saham Konvensional Periode 2009-2012”, Binus Business Review Vol. 5 No 1. Jakarta : Binus University

IDX “Index Saham Jakarta Islamic Index 2013-2017” http://www.idx.co.id/datapasar/data-saham/indekssahan/diakses 28 September 2018

Kandarisa, Nur Aini (2013). "Perkembangan dan Hambatan Reksadana Syariah di Indonesia", Kajian Teori, Univ. Surabaya

Lamban, Gustin Rima (2017). "Analisis pengaruh pendapatan Bagi Hasil Pembiayaan Mudharabah Terhadap Return on Invesment (ROI) pada PT. BNI Syariah Kantor Cabang Palembang” Tugas Akhir. Universitas Islam Nedri Raden Fatah Palembang

Lestari, Winda Rika (2015). "Kinerja Reksadana Saham da Reksadana Saham Konvensional”, Jurnalister Manajemen, Mag Vol. 01 No. 1 Bandar Lampung: Informatic and Business Instittute Darmajaya

Margaretha, Farah (2014). "Perbedaan Kinerja Reksa.dana Konvensional dan Syariah", Jurnal Manajemen \& Bisnis, Trisakti.

Masruroh, Aini (2014). “Konsep Dasas Investasi.Reksadana”, Jurnal Filsaf Budaya Hukum. Jakarta : UIN Jakarta.

Putri, Diah Tri Handayani, Saparila Worokinasih, (2018). "Analisis Kinerja Investasi Reksa dana Syariah Di Indonesia dengan Metode Sharpe, Treynor dan Jansen", Jurnalministrasi BisnisAd Vol.59 No.1. Malang : Universitas Brawijaya.

Qomariah, Nurul, Maheni Ika Sari, Dian Asih Budiarti, (2016). "Perbandingan Kinerja Reksadana Konvensional (Pada Reksadana saham dana Reksadana Pendapatan Tetap yang Terdaftar di BEI Periode 2010-2014”, Jurnal Keuangan dan Perbankan Vol. 20, No 3. Jember: Universitas Muhammadiyah Jember.

Rahmah, Azizatur (2016). "Analisis. Perbandingan Kinerja Reksa dana syariah dan Kinerja Reksa Dana Konvensional dengan Metode Sharpe, Treynor dan Jensen”, Analytica Islamica, Vol. 5 No. 1. Medan : Universitas Islam Negri Sumatera Utara Medan.

Ramdhono, Agus Maulana, A Tulus Sartono, Muhyidin (2001). "Investasi Reksa dana dengan Sistem Mudharabah oleh PT. Bank Syariah Mandiri Pekalongan", Diponegoro Law Review Vol. 1, No.4 Semarang : Universitas Diponegoro. 
Reksa dana syariah. 2013-2017 "Statistik. Nilai Aktiva Bersih Reksa dana Syariah", https://reksadana.ojk.go.id/Public/StatistikNABReksadanaPublic. aspx, diakses 21 September 2018.

Sujarweni, V Wiratna. (2015). “Metodologi Penelitian Bisnis dan Ekonomi”. Makassar: Pustaka Baru Press

Utami, Herlina (2017). "Pengaruh Inflasi, Kurs dan.BI Rate Terhadap Nilai Aktiva Bersih (NAB) Reksadana Syariah di Indonesia 2010-2016", Jurnal Akuntansi Vol. 04, No.01. Tulungagung: IAIN Tulungagung. 